\section{Удк 005.935:336}

JEL classification: C52, E62, G22

\section{Світлана КОРОЛь}

кандидат економічних наук, доцент, кафедра фінансів,

Івано-Франківський національний технічний університет нафти і газу, Україна E-mail: svitlana.korol@nung.edu.ua https://orcid.org/0000-0002-4804-7612 http://www.researcherid.com/rid/AAS-19782020

\section{Ірина IBAШKIB}

кандидат економічних наук, старший науковий співробітник, старший науковий співробітник відділу науково-консультаційного та інформаційного забезпечення економіки та маркетингу, Прикарпатська державна сільськогосподарська дослідна станція Інституту сільського господарства Карпатського регіону НААН, Україна E-mail: i.ivach@ukr.net https://orcid.org/0000-0002-8135-8260 http://www.researcherid.com/rid/ AAQ-31592020

(C) Світлана Король, Ірина Івашків, 2021

Отримано: 22.04.2021 p.

Прорецензовано: 12.05.2021 р.

Рекомендовано до друку: 26.05.2021 р. Опубліковано: 26.05.2021 р.

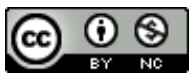

Ця стаття розповсюджується на умовах ліцензії Creative Commons AttributionNonCommercial 4. 0, яка дозволяє необмежене повторне використання, розповсюдження та відтворення на будь-якому носії, за умови правильного цитування оригінальної роботи.
Світлана Король (Україна) Ірина Івашків (Україна)

\section{НАПРЯМИ ВИКОРИСТАННЯ ФІНАНСОВИХ РЕСУРСІВ СТРАХОВИКА КРІЗЬ ПРИЗМУ СИСТЕМИ КОНТРОЛІНГУ}

АнОТАЦІя

Вступ. В умовах постійних викликів сьогодення запорукою виживання та основою стабільного розвитку страхових компаній виступає ефективне управління фінансовими ресурсами, вміле використання яких уможливлює стійку конкурентну позицію на страховому ринку і визначає вектори їх розвитку. Саме фінансові ресурси страховиків виступають одним із найважливіших ресурсів, які призначені задля забезпечення їхньої діяльності. Так як страхова, фінансова та інвестиційна діяльність страховиків тісно пов'язані між собою, то використання їх фінансових ресурсів спрямовується не тільки на здійснення страхових виплат, але й на інвестування. Власне, вміле управління фінансовими ресурсами виступає основою для фінансової стійкості і конкурентоспроможності на страховому ринку, яка стимулює впровадження сучасних методів і підходів у сфері управління. Тому, якраз контролінг виступає чи не єдиноможливим інструментом для побудови оптимізованих систем управління у діяльності страховиків. На всіх рівнях управління він дозволяє забезпечити своєчасною і потрібною інформацією з метою прийняття оптимальних рішень. Дослідження процесу побудови системи страхового контролінгу в межах функціонування страхової компанії з метою оптимізованого використання фінансових ресурсів дасть можливість визначити актуальні інструменти контролінгу та ефективність запровадження системи контролінгу на прикладі страхової компанії. Вагомість фінансових ресурсів у фінансовогосподарській діяльності страхових компаній і можливість їх оптимізації у системі контролінгу в умовах сьогодення набуває особливої актуальності, що потребує подальших досліджень.

Мета. Заініціювати процес побудови системи страхового контролінгу в межах функціонування страхової компанії, що дасть змогу оптимізувати напрями використання її фінансових ресурсів.

Метод (методологія).У процесі дослідження використано такі методи, як логічний, що дозволив проаналізувати наукові праці у площині фінансових ресурсів страховика; аналітичний, який був застосований з метою аналізу та оцінки витрат на запровадження системи контролінгу, а також ефективності ії застосування; графічний, що дав змогу інтерпретувати процес побудови системи страхового контролінгу в межах функціонування страхової компанії у наочному вигляді.

Результати. Визначено значимість фінансових ресурсів у діяльності страхових компаній. Виявлено роль контролінгу 3 метою оптимізованого використання фінансових ресурсів страховиків. Виокремлено переваги та недоліки створення служби контролінгу в межах діяльності страхової компанії, що дозволило побачити, що створення такої системи має більше переваг ніж недоліків. Рекомендовано систему актуальних інструментів контролінгу для страховиків. Запропонований візуальний процес побудови системи 
страхового контролінгу в межах функціонування страхової компанії. Наведена характеристика побудови відділу контролінгу на прикладі ПрАТ СК «Євроінс Україна». Визначена ефективність запровадження системи контролінгу на ПрАТ СК «Євроінс Україна» з використанням показника чистої приведеної вартості грошових потоків. В результаті розрахунків визначено, що запровадження системи контролінгу в страховій компанії $€$ доцільним. Встановлено, що практичні аспекти дослідження фінансових ресурсів у системі контролінгу страхових компаній потребують подальшого вивчення у напрямі оптимізації їх використання.

Король С., Івашків І. Напрями використання фінансових ресурсів страховика крізь призму системи контролінгу. Економічний аналіз. 2021. Том 31. № 2. С. 148-159.

DOI: https://doi.org/10.35774/econa2021.02.148

Ключові слова: фінансові ресурси; контролінг; страхова компанія; використання фінансових ресурсів; страхова діяльність; оптимізація. 


\section{UDC 005.935:336}

\section{JEL classification: C52, E62, G22}

\section{Svitlana KOROL}

PhD, Associated Professor,

Department of Finance,

Ivano-Frankivsk National Technical University of Oil and Gas, Ukraine

E-mail: svitlana.korol@nung.edu.ua

https://orcid.org/0000-0002-4804-7612

http://www.researcherid.com/rid/AAS-19782020

\section{Ivashkiv IRYNA}

$P h D$, Senior Researcher, senior researcher of the department of scientific-advisory and information support of economics and marketing, Precarpathian State Agricultural Experimental Station of the Institute of Agriculture of the Carpathian Region NAAS, Ukraine

E-mail: i.ivach@ukr.net

https://orcid.org/0000-0002-8135-8260 http://www.researcherid.com/rid/ AAQ-31592020

(C) Svitlana Korol, Iryna Ivashkiv, 2021

Received: 22.04.2021

Revised: 12.05.2021

Accepted: 26.05.2021

Online publication date: 26.05 .2021

\section{(i) \&}

This is an Open Access article, distributed under the terms of the Creative Commons AttributionNonCommercial 4. 0 license, which permits unrestricted re-use, distribution, and reproduction in any medium, provided the original work is properly cited.
Svitlana Korol (Ukraine) Iryna Ivashkiv (Ukraine)

\section{DIRECTIONS OF USING THE INSURER'S FINANCIAL RESOURCES THROUGH THE PRISM OF THE CONTROLLING SYSTEM}

\author{
ABstract
}

Introduction. Given the constant challenges of today, the key to survival and the basis of stable development of insurance companies is the effective management of financial resources, the skillful use of which allows a stable competitive position in the insurance market and determines the vectors of their development. It is the financial resources of insurers that are one of the most important resources that are designed to support their activities. Since the insurance, financial and investment activities of insurers are closely linked, the use of their financial resources is aimed not only at making insurance payments, but also at investing. In fact, skillful management of financial resources is the basis for financial stability and competitiveness in the insurance market, which stimulates the introduction of modern methods and approaches in the field of management. Therefore, just controlling is almost the only possible tool for building optimized management systems in the activities of insurers. At all levels of government, it allows you to provide timely and relevant information in order to make optimal decisions. The study of the process of building an insurance controlling system within the operation of the insurance company in order to optimize the use of financial resources will determine the current controlling tools and the effectiveness of the controlling system on the example of the insurance company. The importance of financial resources in the financial and economic activities of insurance companies and the possibility of their optimization in the controlling system in today's conditions becomes especially relevant, which requires further research.

Purpose. Initiate the process of building an insurance controlling system within the functioning of the insurance company, which will allow optimizing the use of its financial resources.

Method (methodology). In the process of research such methods were used as logical, which allowed to analyze scientific works in the field of financial resources of the insurer; analytical, which was used to analyze and evaluate the costs of implementing a controlling system, as well as the effectiveness of its application; graphic, which made it possible to interpret the process of building an insurance controlling system within the functioning of the insurance company in a visual form.

Results. The importance of financial resources in the activities of insurance companies is determined. The role of controlling for the purpose of optimized utilization of financial resources of insurers is revealed. The advantages and disadvantages of creating a controlling service within the activities of the insurance company are highlighted, which allowed us to see that the creation of such a system has more advantages than disadvantages. A system of topical controlling tools for insurers is recommended. A visual process of building an insurance controlling system within the operation of an insurance company is proposed. The characteristics of the construction of the controlling department on the example of PJSC IC "Euroins Ukraine" are given. The 
efficiency of introduction of the controlling system at PJSC IC "Euroins Ukraine" with the use of the indicator of net present value of cash flows is determined. As a result of calculations it is determined that the introduction of a controlling system in the insurance company is appropriate. It is established that the practical aspects of the study of financial resources in the system of controlling insurance companies need further study in the direction of optimizing their use.

Korol, S., \& Ivashkiv, I. (2021). Directions of using the insurer's financial resources through the prism of the controlling system. Economic analysis, 31 (2), 148-159.

\section{DOI: https://doi.org/10.35774/econa2021.02.148}

Keywords: financial resources; controlling; Insurance Company; use of financial resources; insurance activity; optimization. 


\section{Вступ}

Страхові компанії виступають важливим джерелом інвестиційних ресурсів, особливо в умовах перманентних кризових явищ. Тому ефективність дослідження проблем формування фінансових ресурсів страховиків визначається чітким розумінням їх сутності як сукупності тимчасово вільних коштів страховика, які знаходяться в його розпорядженні й використовуються для проведення страхових операцій та здійснення інвестиційної діяльності [1, c. 108]. Це свідчить про те, що саме специфічні особливості щодо формування складу і структури фінансових ресурсів страховиків, значимість їх фінансових результатів значною мірою окреслюють подальші напрями їх використання в поточній страховій (проведення операцій страхування, співстрахування та перестрахування) або фінансово-інвестиційній діяльності (купівля-продаж цінних паперів, нерухомості й операції з такими фінансовими активами, як кредити, зокрема іпотечні).

Фінансові ресурси страхової компанії - це сукупність тимчасово вільних коштів страховика, які знаходяться у господарському обороті та використовуються для проведення страхових операцій та здійснення інвестиційної діяльності [1]. Відтак, використання фінансових ресурсів страховика фактично $€$ витрачанням грошових коштів протягом його діяльності.

Водночас, від напрямів використання фінансових ресурсів страховика залежить фінансовий результат, ефективність діяльності та загальний фінансовий стан страхової організації. Таким чином тут можна говорити про управління капіталом страховика. Головним завданням управління капіталом, $€$ формування його оптимальної структури 3 урахуванням гарантованого рівня дохідності й ризику. Тобто йдеться про ефективність корпоративного управління та інвестиційну привабливість страхової компанії [2, с.84].

Тому у кінцевому підсумку фінансові ресурси визначають не тільки фінансову стійкість страхової компанії, але й конкурентну позицію на страховому ринку. Саме конкурентна боротьба стимулює впроваджувати у практичну діяльність новітні методи і підходи у сфері управління, що, в свою чергу, дає змогу підвищити рівень їх економічного розвитку і наростити обсяги чистого прибутку. В умовах викликів сьогодення процес дослідження механізмів покращення управління знаходиться у безперебійному стані.

Відомо, що управління - це вплив суб'єкта управління на об'єкт управління для досягнення стратегічних і тактичних цілей. Ефективність управління - це, 3 одного боку, своєчасне досягнення поставлених цілей 3 найменшим використанням ресурсів. 3 іншого боку, під ефективністю мається на увазі якість, тобто ефективне управління - це управління, спрямоване на підвищення якісного рівня страхової компанії за допомогою специфічних методів та інструментів [3, с. 106]. Контролінг за своєю сутністю є прикладом пошуку побудови оптимальних систем управління, а концепція його запровадження покликана забезпечити підвищення управління у межах окремо взятого підприємства через нарощення рівня синхронності роботи окремих його структурних підрозділів [4, с. 328].

Теоретична база виміру фінансових ресурсів у площині застосування контролінгу $\epsilon$ досить розвинутою, зокрема серед українських науковців необхідно виділити таких як Бланд Д. [1], Брохун Н. [11], Гуляїва Е. [5], Дубина М. [6], Івашків І. [2], Кірдякіна Н. [10], Клімов А. [9], Король С. [2], Мозіль О. [10], Нагайчук Н. [3], Пінчук А. [4], Ткаченко Н. [7], Тунік М. [4; 6], Цигилик І. [10], Шешукова Т. [5], Шкарлет С. [6] та інших, однак застосування контролінгу у практиці страховиків $€$ незначним.

Методологічну основу забезпечення даного дослідження становлять основні постулати, теорії, моделі та концепції з проблематики ефективного використання фінансових ресурсів у системі контролінгу страхових компаній в Україні.

Акцентуючи увагу на дослідженнях науковців, необхідним $€$ подальше дослідження системи контролінгу в межах функціонування страховиків, що дасть змогу оптимізувати напрями використання фінансових ресурсів і визначити ефективність його застосування на практиці.

\section{Мета статті}

Мета статті - заініціювати процес побудови системи страхового контролінгу в межах функціонування страхової компанії, що дасть змогу оптимізувати напрями використання їі фінансових ресурсів.

\section{Виклад основного матеріалу дослідження}

Загалом контролінг представляє собою спеціальну систему методів та інструментів, яка спрямована на функціональну підтримку менеджменту підприємства (зокрема фінансового менеджменту) і включає в себе інформаційне забезпечення, планування, координацію, контроль та внутрішній консалтинг. Відтак призначення контролінгу в страховій компанії - забезпечити управлінців усіх рівнів своєчасною і необхідною інформацією для прийняття оптимальних рішень операційного і стратегічного характеру [5]. 
Важливими аспектами впровадження системи контролінгу в страховій компанії $\epsilon$ розуміння переваг та недоліків реалізації такої системи у межах ії діяльності, оскільки детальне опрацювання позитивних та негативних ефектів від формування зазначеної системи дає змогу об'єктивно оцінити доцільність її створення. В табл. 1 систематизовано переваги та недоліки створення служби контролінгу у межах діяльності страхової компанії.

Таким чином з табл. 1 бачимо, що створення системи контролінгу в страховій компанії має більше переваг ніж недоліків, а отже, $є$ існує сенс реалізації такого проекту.

До основних завдань контролінгу, крім планування й контролю, відноситься й оптимальне використання ресурсів компанії. Тому, для подальшого аналізу фінансових ресурсів у системі контролінгу, зосередимо увагу на страховій компанії, якій, власне, необхідно впровадити таку систему, зокрема - на ПрАТ СК «Євроінс Україна» [8]. Практичний досвід страховиків, у яких відсутній контролінг, вказує на те, що спостерігається недосконалість менеджменту і приділення недостатньої уваги управлінню фінансовими потоками.

Головними завданнями контролінгу $\epsilon$ його орієнтація на досягнення стратегічних цілей компанії засобами моніторингу та дослідження в економіці та в компанії, оптимізація бізнеспроцесів компанії, безперервний управлінський контроль діяльності, складання звітів, аналітика відхилень у діяльності, ліквідація «вузьких місць», розроблення заходів щодо максимізації ефективності діяльності компанії та методологічна підтримка з метою отримання менеджерами впевненості в прийнятті рішень. Досягнення вказаних завдань можливе за умови впровадження злагодженої та гнучкої системи інструментів контролінгу, наведених у табл. 2.

Складність сучасних систем забезпечення прийняття рішень вимагає посилення узгодженості в діях менеджерів, впровадження адекватної системи інструментів контролінгу, що дозволить страховій компанії вчасно приймати зважені управлінські рішення, гарантуючи зростання факторів розвитку бізнесу. Метою впровадження і застосування системи інструментів контролінгу $€$ отримання даних, їх оброблення й перетворення в інформацію для управління та прийняття рішень. Система контролінгу забезпечує більш досконале управління страховою компанією, дозволяє підвищити рівень координованості в прийнятті управлінських рішень.

Запровадження системи страхового контролінгу, крім теоретичних аспектів ії формування, вимагає розроблення поетапного комплексу заходів, реалізація яких дає можливість більш системно підійти до створення страхового контролінгу. 3 цією метою розроблено процес побудови зазначеної системи для ПрАТ СК «Євроінс Україна».Формування системи контролінгу на ПрАТ СК «Євроінс Україна» буде відбуватись в декілька етапів (рис. 1). 


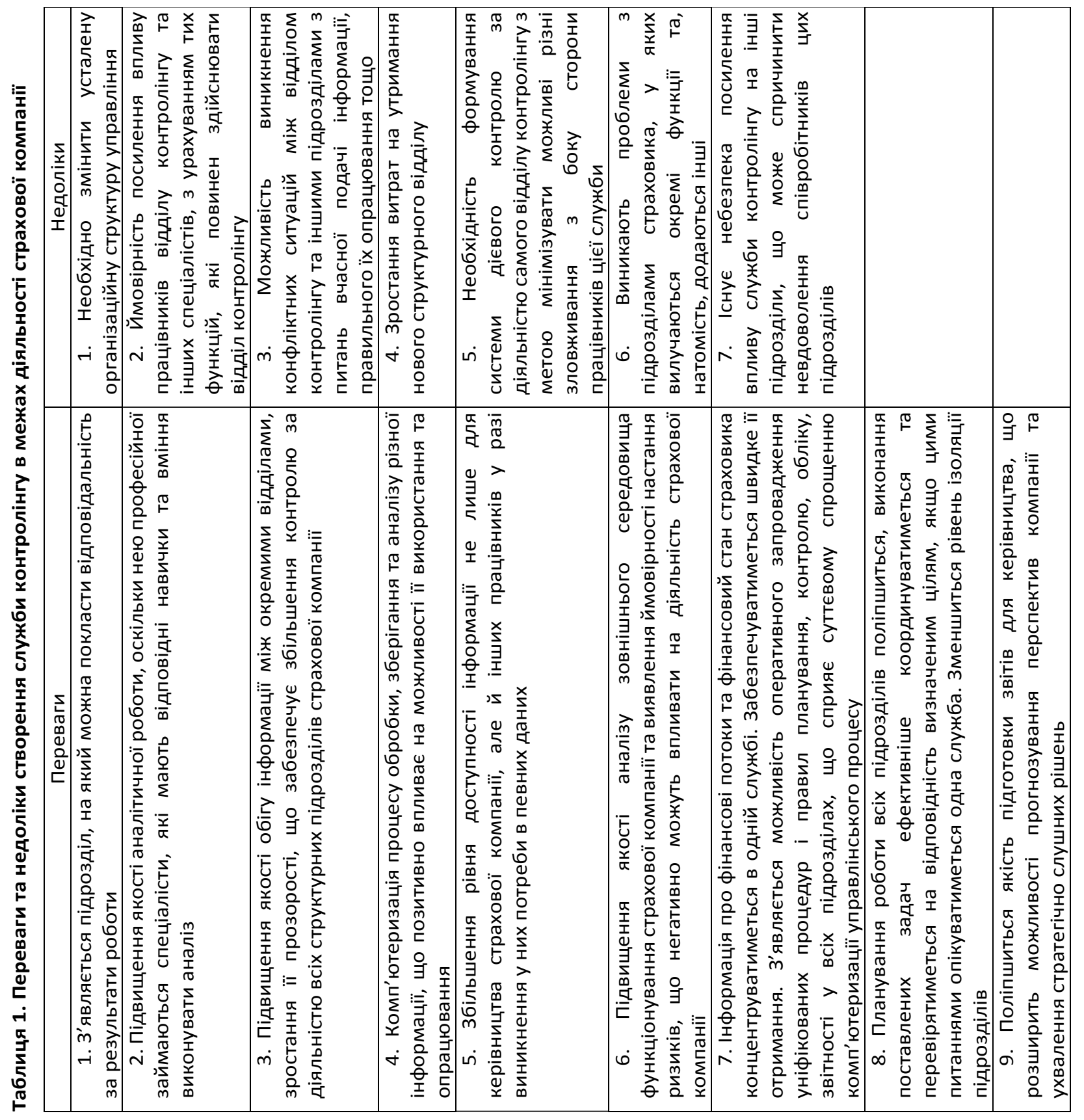

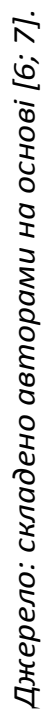


Таблиця 2. Рекомендована система інструментів контролінгу для ПрАТ СК «Євроінс Україна»

\begin{tabular}{|c|c|}
\hline Вид & Характеристика \\
\hline $\begin{array}{l}\text { Управління } \\
\text { корпоративною } \\
\text { вартістю VALUE } \\
\text { BASED } \\
\text { MANAGEMENT) }\end{array}$ & $\begin{array}{l}\text { Створення стратегічної системи управління вартістю компанії з метою ї̈ максимізації - } \\
\text { основне завдання будь-якого менеджменту. До уваги беруться фактори, що } \\
\text { безпосередньо впливають на вартість бізнесу, ефективність діяльності компанії, зокрема } \\
\text { основні фактори вартості компанії, розроблення та впровадження інструментарію й } \\
\text { механізмів управління вартістю з метою формування концепції вартісного підходу в } \\
\text { управлінні }\end{array}$ \\
\hline $\begin{array}{l}\text { Система } \\
\text { збалансованих } \\
\text { показників } \\
\text { (BALANCED } \\
\text { SCORECARD) }\end{array}$ & $\begin{array}{l}\text { Цей інструмент контролінгу дозволяє гармонізувати фінансові показники результатів } \\
\text { діяльності минулого періоду з стратегічними показниками майбутнього, перш за все, } \\
\text { використовуючи методику КРІ (key performance indication) - систему ключових } \\
\text { показників діяльності компанії, яка дає визначення та оцінювання стратегічним і } \\
\text { практичним цілям компанії з метою контролю ділової активності співробітників і } \\
\text { компанії в цілому. Це система інструментів вимірудосягнення поставлених цілей }\end{array}$ \\
\hline $\begin{array}{c}\text { Управління } \\
\text { бюджетуванням }\end{array}$ & $\begin{array}{l}\text { Зміни всередині організації проходять як реакція на зміни в зовнішньому середовищі, } \\
\text { що, в свою чергу, зумовлює необхідність впровадження цього інструменту контролінгу, } \\
\text { що дозволяє менеджменту компанії аналізувати та контролювати доцільність та } \\
\text { ефективність бюджетування певних напрямків діяльності. Складаючи поточний, } \\
\text { інвестиційний та фінансовий бюджет, аналізуючи планові показники з фактичними та } \\
\text { контролюючи виконання бюджетів, страхова компанія забезпечує підвищення } \\
\text { фінансової стійкості, може виявити несприятливі фактори, що впливають на діяльність } \\
\text { страховика ще на стадії виникнення та нейтралізувати їх вплив. }\end{array}$ \\
\hline $\begin{array}{c}\text { Маржинальний } \\
\text { аналіз }\end{array}$ & $\begin{array}{l}\text { За допомогою маржинального аналізу величин у точці беззбитковості визначаються: } \\
\text { а) графік беззбитковості; } \\
\text { б) критичний обсяг продажів; } \\
\text { в) критичний обсяг виробництва та ін. }\end{array}$ \\
\hline $\begin{array}{c}\text { Аналіз точки } \\
\text { беззбитковості }\end{array}$ & $\begin{array}{l}\text { Застосування цього інструменту контролінгу обумовлено тим, що це один з основних } \\
\text { методів оцінювання ефективності інвестиційних проектів. Аналіз беззбитковості } \\
\text { дозволяє компанії визначитись } 3 \text { необхідними обсягами продажів, тарифами та } \\
\text { маржинальними коефіцієнтами під час планування показників прибутку. }\end{array}$ \\
\hline
\end{tabular}

Джерело: складено авторами на основі [9; 10]. 


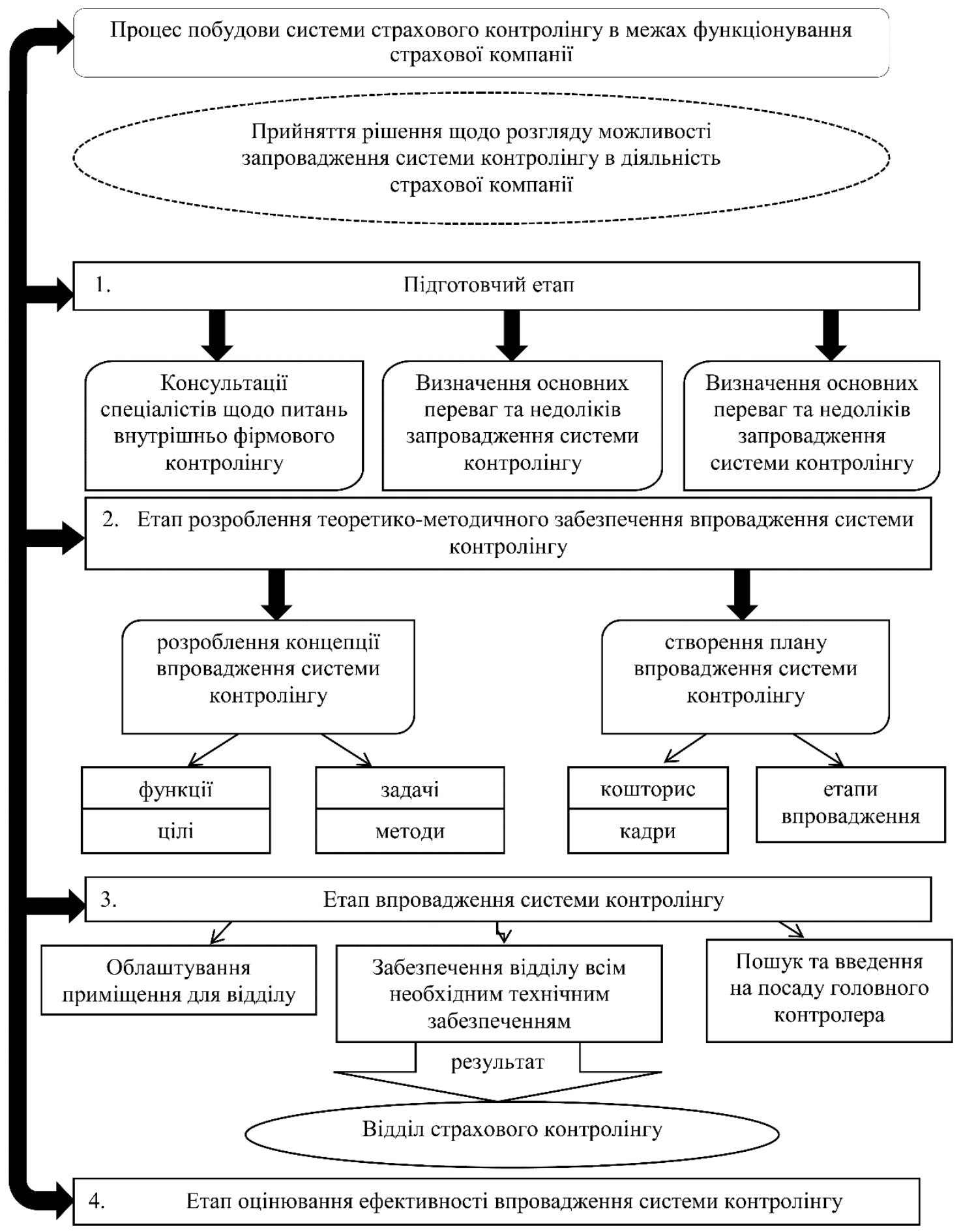

Рис. 1. Процес побудови системи страхового контролінгу в межах функціонування страхової компанії Джерело: побудовано авторами на основі $[4 ; 6 ; 7]$. 
Етапи процесу побудови системи страхового контролінгу в межах функціонування страхової компанії:

1. Підготовчий етап - етап, на якому визначається доцільність формування системи контролінгу в межах діяльності страхової компанії, зважуються переваги та недоліки реалізації такої системи.

2. Етап розроблення теоретико-методичного забезпечення впровадження системи страхового контролінгу дає змогу після позитивного рішення щодо формування зазначеної системи забезпечити iї реалізацію необхідними вихідними положеннями.

3. Етап впровадження системи страхового контролінгу дозволяє з урахуванням розроблених концепції, кошторису поступово побудувати зазначену систему відповідно до плану ії створення.

4. Етап оцінювання ефективності впровадження системи контролінгу дозволяє, зрозуміти чи о запровадження системи контролінгу $є$ економічно виправдане.

Таким чином, запровадження наведеного процесу формування страхового контролінгу, на наш погляд, дозволить побудувати ефективнопрацюючу систему з практичною ідентифікацією ії основних функцій та позитивних ефектів для розвитку страхової компанії. Загалом створений відділ контролінгу на ПрАТ СК «Євроінс Україна» буде відповідати таким характеристикам (табл. 3).

Таблиця 3. Характеристика побудови відділу контролінгу ПрАТ СК «Євроінс Україна»

\begin{tabular}{|c|l|}
\hline Ознака & \multicolumn{1}{|c|}{ Характеристика } \\
\hline $\begin{array}{c}\text { Система } \\
\text { підпорядкування }\end{array}$ & Відділ контролінгу буде включений до фінансового департаменту компанії \\
\hline Модель структури & Структура відділу проста, з штатним розписом, кількість посад-3 працівника \\
\hline $\begin{array}{c}\text { Вплив інших } \\
\text { підрозділів }\end{array}$ & $\begin{array}{l}\text { Досить вагомий вплив інших підрозділів на функціонування відділу контролінгу, } \\
\text { окремого відділу неможливо забезпечити наявність фахівців із всіх питань, що } \\
\text { вирішуються працівниками зазначеного структурного підрозділу. }\end{array}$ \\
\hline $\begin{array}{c}\text { Рівень спеціалізації } \\
\text { працівників }\end{array}$ & $\begin{array}{l}\text { Наявність у межах відділу контролінгу більш універсальних спеціалістів, які здатні } \\
\text { виковати аналітичну роботу та розробляти заходи щодо подальшого удосконалення } \\
\text { системи обігу інформаціїу межах діяльності страхової компанії. }\end{array}$ \\
\hline
\end{tabular}

Джерело: складено авторами на основі [4; 6-8].

Впровадження системи контролінгу в страховій компанії пов'язане з виникненням додаткових витрат. В табл. 4 наведено основні витрати, які компанія понесе в результаті реалізації проекту.

Таблиця 4. Витрати на запровадження системи контролінгу на ПрАТ СК «Євроінс Україна»

\begin{tabular}{|l|c|}
\hline \multicolumn{1}{|c|}{ Витрати } & Сума, грн. \\
\hline $\begin{array}{l}\text { Витрати на консультаційні послуги щодо } \\
\text { впровадження системи контролінгу }\end{array}$ & 1000 \\
\hline Облаштування приміщення для відділу & 25000 \\
\hline Придбання меблів & 20000 \\
\hline Придбання комп'ютерної техніки & 10000 \\
\hline $\begin{array}{l}\text { Купівля інформаційного спеціалізованого } \\
\text { забезпечення }\end{array}$ & 1000 \\
\hline \multicolumn{1}{|c|}{ Разові } & 125000 \\
\hline Заробітна плата працівників & $24000 /$ міс \\
\hline Комунальні послуги & $200 /$ міс \\
\hline Оплата послуг зв'язку & $180 /$ міс \\
\hline Витрати на канцелярію & $120 /$ міс \\
\hline Оплата послуг інтернет-провайдера & $150 /$ міс \\
\hline \multicolumn{1}{|c|}{ Періодичні } & $25650 /$ міс \\
\hline
\end{tabular}

Джерело: розраховано авторами. 
При дослідженні впровадження системи контролінгу у страховій компанії, необхідно визначити також економічну ефективність запропонованого заходу. Головною метою створення системи контролінгу на ПрАТ СК «Євроінс Україна» $€$ покращення управління фінансовими потоками компанії. Саме завдяки їхньому активному управлінню можна забезпечити більш раціональне й ощадливе використання фінансових ресурсів, а також знизити залежність темпів розвитку страховиків від зовнішніх факторів.

Отож, визначення ефекту від впровадження системи контролінгу здійснимо методом 3 використанням показника чистої приведеної вартості грошових потоків (NPV - Net Present Value) [11]:

$$
N P V=\sum_{i=1}^{n} \frac{\Delta C F_{t}-\Delta M_{t}}{(1+r)^{t}}-I K_{0}
$$

де $\Delta C F_{t}, \Delta M_{t}$ - відповідно величина збільшення грошового потоку та додаткових управлінських витрат, пов'язаних із функціонуванням служби контролінгу в періоді t;

$I K_{0}$ - початкові інвестиційні витрати на впровадження системи контролінгу;

$r$ - ставка дисконтування.

В табл. 5 наведені розрахунки, які обґрунтовують економічну доцільність введення системи контролінгу на ПрАТ СК «Євроінс Україна».

Таблиця 5. Ефективність запровадження системи контролінгу на ПрАТ СК «Євроінс Україна»

\begin{tabular}{|c|c|c|c|c|c|c|}
\hline Показник & $\begin{array}{c}\text { Назва } \\
\text { показника }\end{array}$ & $\begin{array}{l}\text { IV квартал } \\
2021 \text { року }\end{array}$ & $\begin{array}{l}\text { I квартал } \\
2022 \text { року }\end{array}$ & $\begin{array}{l}\text { II квартал } \\
2022 \text { року }\end{array}$ & $\begin{array}{l}\text { III квартал } \\
2022 \text { року }\end{array}$ & $\begin{array}{l}\text { IV квартал } \\
2022 \text { року }\end{array}$ \\
\hline $\begin{array}{l}\text { Грошовий потік компанії } \\
\text { після ведення відділу } \\
\text { контролінгу, грн. }\end{array}$ & $\Delta C F_{t}$ & - & 60000 & 70000 & 85000 & 110000 \\
\hline $\begin{array}{l}\text { Управлінські витрати на } \\
\text { утримання відділу, грн. }\end{array}$ & $\Delta M_{t}$ & - & 76950 & 76950 & 76950 & 76950 \\
\hline $\begin{array}{l}\text { Початкові інвестиції на } \\
\text { створення відділу, грн. }\end{array}$ & $I K_{0}$ & 25650 & 0 & 0 & 0 & 0 \\
\hline Ставка дисконтування, \% & $r$ & - & $25 \%$ & $25 \%$ & $25 \%$ & $25 \%$ \\
\hline Коефіцієнт дисконтування & $1 /(1+r)$ & - & 0,8 & 0,64 & 0,51 & 0,41 \\
\hline $\begin{array}{l}\text { Чисті дисконтовані грошові } \\
\text { потоки, грн }\end{array}$ & & & $-21187,5$ & $-10859,4$ & 15784,31 & 80609,76 \\
\hline $\begin{array}{l}\text { NPV функціонування } \\
\text { відділу, грн. }\end{array}$ & NPV & \multicolumn{5}{|c|}{38697,19} \\
\hline
\end{tabular}

Джерело: розраховано авторами.

Таким чином, запровадження системи контролінгу на ПрАТ СК «Євроінс Україна» $\epsilon$ доцільним, оскільки розраховане значення NPV $\epsilon$ додатним. Також, всі витрати понесені на реалізацію проекту окупляться в III кварталі 2022 року. В цілому впровадження системи контролінгу себе економічно виправдовує та $\epsilon$ економічно доцільним у досліджуваній страховій компанії, так як дозволить забезпечити більш раціональне й ощадливе використання фінансових ресурсів.

\section{Висновки та перспективи подальших розвідок}

Результати проведеного дослідження свідчать про те, що необхідно оптимізувати напрями використання фінансових ресурсів страховика через систему контролінгу. В результаті розгляду напрямів використання фінансових ресурсів страховика визначено, що використання фінансових ресурсів страховика відбувається внаслідок здійснення ним операційної (страхової), фінансової та інвестиційної діяльності. Страховий сектор відіграє важливу роль в інвестиційних процесах. Встановлено, що фінансові ресурси страховика мають різні інвестиційні можливості в залежності від їх структури.

Для ПрАТ СК «Євроінс Україна» було запропоновано створення системи контролінгу. Було визначено, що створення такої системи має більше переваг ніж недоліків. Обрано систему інструментів та визначено етапи процесу формування служби контролінгу в компанії. Даний проєкт розроблений 3 метою покращення ефективності управління грошовими потоками страхової компанії, а отже, визначення ефекту від 
впровадження системи контролінгу здійснено 3 використанням показника чистої приведеної вартості грошових потоків. В результаті розрахунків визначено, що запровадження системи контролінгу в страховій компанії є доцільним.

Проте на перспективу необхідно і надалі оптимізовувати напрями використання фінансових ресурсів страховика крізь призму системи контролінгу. Загалом практичні аспекти оптимізації напрямів використання фінансових ресурсів страховиків потребують подальшого вивчення, що передбачає впровадження їх напрямів в умовах сьогодення.

\section{СПИСОК ВИКОРИСТАНИХ ДЖЕРЕЛ}

1. Бланд Д. Страхование: принципь и практика: пер. с англ. сост. Д Бланд. М.: Финансы и статистика, 1998. 416 c.

2. Ivashkiv I., Korol S. and others. Strategies, models and technologies of economic systems management in the context of international economic integration: collective monograph. Riga (Latvia), 2020. 296 p.

3. Нагайчук Н. Г. Управління капіталом страхових компаній Фінанси України. 2008. №11. С. 106-116.

4. Пінчук А., Тунік М. Механізм впровадження системи контролінгу у діяльність страхових компаній. Проблеми $i$ перспективи економіки та управління. № 2(6). (2016). С. $327-$ 339.

\section{REFERENCES}

1. Bland, D. (1998). Strakhuvannya: pryntsypy ta praktyka: per. s anhl. sost. D. Bland. Moscow: Finansy i statistika.

2. Ivashkiv, I., \& Korol', S. (2020). Stratehiyi, modeli ta tekhnolohiyi upravlinnya ekonomichnymy systemamy $v$ konteksti mizhnarodnoyi ekonomichnoyi intehratsiyi: kolektyvna monohrafiya. Ryha (Latviya).

3. Nahaychuk, N. H. (2008) Upravlinnya kapitalom strakhovykh kompaniy. Finansy Ukrayiny, 11, 106-116.

4. Pinchuk, A., \& Tunik, M. (2016). Mekhanizm vprovadzhennya system kontrolyu za diyal'nistyu strakhovykh kompaniy. Problemy ta perspektyvy ekonomiky ta upravlinnya, 2 (6), 327-339.
5. Шешукова Т., Гуляїва Е. Теорія i практика контролінгу. Київ: IHФРА-К, 2008. 176 c.

6. Шкарлет С. М., Дубина М. В., Тунік М. В. Особливості створення служби контролінгу у страхових компаніях. Науковий вісник Полісся. № 3 (7). 2016.

7. Ткаченко Н. Основні завдання та інструменти контролінгу фінансової стійкості страхової компанії. Вісник НБУ. 2012. URL: https://essuir.sumdu.edu.ua/bitstre am-

download/123456789/57625/5/Tka chenko.pdf

8. Офіційний сайт ПрАТ СК «Євроінс Україна». URL: https://euroins.com.ua/

5. Sheshukova, T., Hulyayiva, E. (2008). Teoriya i praktyka kontrolinhu. Kyyiv: INFRA-K.

6. Shkarlet, S. M., \& Dubyna, M. V., Tunik M. V. (2016). Osoblyvosti stvorennya sluzhb kontrolinhu $v$ strakhovykh kompaniyakh. Naukovyy visnyk Polissya, 3 (7).

7. Tkachenko, N. (2012). Osnovni zavdannya ta instrumenty kontrolyu finansovoyi stiykosti strakhovoyi kompaniyi. Visnyk NBU. Retrieved from:

https://essuir.sumdu.edu.ua/bitstre am-

download/123456789/57625/5/Tka chenko.pdf.

8. Ofitsiynyy sayt PrAT SK "Yevroins Ukrayina». Retrieved from: https://euroins.com.ua/
9. Клімов А. В. Контролінг в процесі прийняття управлінських рішень в страховій компанії. Вісник Національного технічного університету "Харківський політехнічний інститут". Технічний прогрес $i$ ефективність виробництва. 2006. №1 (41). С. 201-207.

10. Цигилик І. І. Контролінг в систем управління. Актуальні проблеми економіки. 2005. № 3 (45). С. 117 123.

11. Брохун Н. С. Аналіз ефективності впровадження та функціонування системи контролінгу на підприємствах. Вісник жДТУ. 2012. № 4(62). С. 35-38.
9. Klimov, A. V. (2006). Kontrol' u protsesi pryynyattya upravlins'kykh rishen' u strakhoviy kompaniyi. Visnyk Natsional'noho tekhnichnoho universytetu "Kharkivs'kyy politekhnichnyy instytut". Temp. vyp. "Tekhnichnyy prohres ta efektyvnist' vyrobnytstva", 1 (41), 201-207.

10. Tsyhylyk, I. I. (2005). Kontrolinh v systemi upravlinnya. Aktual'ni problemy ekonomiky, 3 (45), 117 123.

11. Brokhun, N. S. (2012). Analiz efektyvnosti vprovadzhennya ta funktsionuvannya system kontrolyu na pidpryyemstvakh. Visnyk ZHDTU, 4 (62), 35-38. 